\title{
Review
}

\section{An overview of respiratory syncytial virus infections in Saudi Arabia}

\author{
Anwar Ahmed ${ }^{1,2}$, Shama Parveen ${ }^{3}$, Sarah M Al-Hassinah ${ }^{1}$, Salman F Al-Amery ${ }^{1,2}$ \\ ${ }_{1}^{1}$ Protein Research Chair, Department of Biochemistry, College of Science, King Saud University, Riyadh, Saudi \\ Arabia \\ ${ }^{2}$ Centre of Excellence in Biotechnology Research, Department of Biochemistry, College of Science, King Saud \\ University, Riyadh, Saudi Arabia \\ ${ }^{3}$ Centre for Interdisciplinary Research in Basic Sciences, Jamia Millia Islamia, New Delhi, India
}

\begin{abstract}
Respiratory syncytial virus (RSV) is a major pathogen of acute respiratory tract infection (ARI) in different geographical regions including Saudi Arabia. Numerous hospital-based investigations have revealed the RSV prevalence between $0.2-54 \%$ in the paediatric population with ARI/ALRI from Saudi Arabia during 1991-2015. Maximum RSV infections occurred in children less than 1 year of age (51-97\%) and male children (51-69\%) were more commonly affected than females (31-49\%). RSV infections are reported mostly during winter season suggesting seasonal distribution of the virus. Other respiratory viruses reported from this region are adenovirus, influenza, parainfluenza, human metapneumovirus and rhinovirus including many mixed infections. A few studies have reported the phylogenetic analysis of the circulating strains of RSV. These studies have revealed that circulating group A-RSV Saudi strains belonged to NA1 and ON1 genotypes and group BRSV viruses clustered in the BA genotype. Molecular characterization of the Saudi strains was further carried out by mutational, selection pressure and glycosylation site analyses. We have compiled all the eighteen studies of RSV infection from Saudi Arabia in the form of this review and concluded that detailed comprehensive surveillance of RSV and other viruses in community and hospital settings is required. Information on the molecular characterization of currently circulating strains of RSV will contribute towards better understanding of the epidemiology and evolutionary dynamics of this viral pathogen. Moreover, the determination of the genetic composition of circulating RSV strains will be important during evaluation of initial vaccine trials.
\end{abstract}

Key words: genotypes; epidemiology; molecular characterization; phylogenetic analysis; respiratory syncytial virus; Saudi Arabia.

J Infect Dev Ctries 2018; 12(11):929-936. doi:10.3855/jidc.10736

(Received 29 July 2018 - Accepted 22 September 2018)

Copyright (C) 2018 Ahmed et al. This is an open-access article distributed under the Creative Commons Attribution License, which permits unrestricted use, distribution, and reproduction in any medium, provided the original work is properly cited.

\section{Introduction}

Respiratory viruses are major contributors to morbidity and mortality due to acute respiratory infection (ARI) especially in the paediatric age group worldwide. Well recognized respiratory viral pathogens include respiratory syncytial virus (RSV), influenza virus (INF-A/B), parainfluenza virus (PIV-1/2/3), human metapneumovirus (hMPV) and adenoviruses. Respiratory syncytial virus (RSV) is one of the major etiological agents of ARI and it is involved in upper respiratory infections (URI) and acute lower respiratory tract infections (ALRI) in children. The severe disease may lead to bronchiolitis and pneumonia in many paediatric patients [1]. RSV is also known as an important respiratory pathogen in adults especially in immunocompromised patients [2] and premature infants with congenital abnormalities such as Down syndrome, cystic fibrosis, atopy and children with chronic lung disease $[3,4]$. In 2005 , RSV was estimated to cause around 33.8 million infections and 2.8-4.3 million hospital admissions with 66,000- 199,000 deaths annually across the world [5]. The global estimates in 2015 did not change much and a total of 33.1 million episodes of RSV resulting in 3.2 million hospital admissions and around 60,000 in hospital deaths were reported [6]. RSV causes seasonal epidemics during winter in temperate countries including Saudi Arabia [7,8] and during rainy season in tropical areas [9]. Re-infections with RSV are common and occur throughout life even in the presence of preexisting antibodies $[10,11]$.

RSV is classified in family Paramyxoviridae, order Mononegavirales and subfamily, Pneumovirinae. RSV is an enveloped, non-segmented single stranded negative sense RNA virus. The genome of the virus is approximately $15.2 \mathrm{~Kb}$ in length which has $10 \mathrm{ORFs}$ and codes for 11 different structural (G, F, SH, M, N, P, L, M21, M2-2) and non-structural proteins (NS1 and NS2) (2). The G (attachment) protein and F (fusion) protein are the trans-membrane surface glycoproteins involved in the attachment and fusion of the virion with the host cell, respectively. They are neutralizing 
antigens and thus vaccine candidates [12]. RSV is classified into two antigenic groups, A and B based on reactivity of monoclonal antibodies to $\mathrm{G}$ protein and its genetic variability $[13,14]$. The $G$ protein shows maximum antigenic and genetic diversity between and within the two groups [15]. It is extensively glycosylated by addition of both $\mathrm{N}$ - and O-linked oligosaccharides that are known to help the virus to evade host immune response [16]. The second hypervariable region, corresponding to the $\mathrm{C}$ terminal region of the $G$ protein, shows overall $G$ gene variability and has been analyzed for molecular epidemiological studies [17-19].

Genetic variations mainly occur in RSV due to mutations and changes in stop codon usage in the $\mathrm{G}$ protein gene. Antigenic variations in the virus are reported due to alterations in the number and frequency of the $\mathrm{N}$ - and O-linked glycosylation sites in the $\mathrm{G}$ protein. Gene clades or genotypes have been described among both the groups of RSV based on the phylogenetic clustering of $\mathrm{G}$ protein gene. Several genotypes have been described among group A RSV, that include GA1-GA7 SAA1SAA2, NA1-NA4 and ON1 [20-23] and for group B RSV includes GB1GB6,SAB1-SAB4,URU1-2, CB1, CBB and BA1BA12 [24-29]. The ON1 and BA genotypes show 72bp and $60 \mathrm{bp}$ duplication in the second hypervariable region of the $G$ protein gene [21,24-28,30]. Phylogenetic analysis of $\mathrm{G}$ protein gene sequences has revealed complex circulation patterns of RSV. Both the antigenic groups of RSV may circulate within the same season in a particular community with one or two dominant genotypes that are replaced by other genotypes in subsequent seasons [31].

RSV has been described as an important pathogen of ARI from Saudi Arabia, the largest country in the Middle East. We have compiled eighteen different reports on RSV infection published during last 25 years (1993 to 2018) in the present review. The search criteria for literature review include PubMed search with RSV and Saudi as keywords and the google search for back references. The last search was done on March 2018. These studies included both ARI and ALRI patients in the paediatric age group less than 5 years of age. Fourteen of these studies were carried out in Riyadh, the capital of Saudi Arabia and one each at Abha [32], Al-Qassim [33], Najran [34] and Jazan [35] (Table1). The present report aims to summarize all these studies in the form of a comprehensive review to highlight the importance of RSV in this region.

\section{RSV prevalence in Saudi Arabia}

There is a paucity of information on the actual disease burden of RSV from Saudi Arabia. Limited hospital based investigations of ARI have been carried out in some cities of Saudi Arabia (Figure 1) and RSV was identified as one of the important viral pathogen in all the studies (Figure 2). In most of the studies, RSV

Table 1. Studies conducted on RSV in Saudi Arabia from 1991 to 2018.

\begin{tabular}{|c|c|c|c|c|c|c|c|c|}
\hline S. No & Study site (year) & $\begin{array}{l}\text { Samples } \\
\text { tested }\end{array}$ & $\begin{array}{c}\text { Virus positive } \\
(\%)\end{array}$ & RSV A, B (\%) & $\begin{array}{c}\text { RSV } \\
\text { prevalence } \\
(\%)\end{array}$ & $\begin{array}{c}\text { Method (DFA/culture/ } \\
\text { ELISA/PCR/real time } \\
\text { PCR) }\end{array}$ & Genotypes & Reference \\
\hline 1 & Riyadh (1991-92) & 127 & $70(55 \%)$ & $69(98.6 \%)$ & 54.3 & DFA/culture & - & [36] \\
\hline 2 & Riyadh (1992-93) & 485 & 74 & 52 & 70.2 & DFA/culture & - & [37] \\
\hline 3 & Riyadh (1993-96) & 1429 & $522(37)$ & $413(79)$ & 28.9 & DFA/culture & - & [38] \\
\hline 4 & Riyadh (1993-96) & 256 & $73(28.5)$ & $73(28.5)$ & 28.5 & -- & - & [39] \\
\hline 5 & Abha, (1997-2001) & 51 & $45(88.2)$ & $18(40)$ & 35.2 & DFA/ELISA & - & [32] \\
\hline 6 & Riyadh (1999-2003) & 4575 & $884(19.3)$ & $884(19.3)$ & 19.3 & DFA & - & [40] \\
\hline 7 & Al-Qassim (2003-04) & 282 & $128(45.4)$ & $128(45.4)$ & 45.3 & DFA & - & [33] \\
\hline 8 & Riyadh (2006-07) & 10,617 & $883(8.3)$ & $733(83)$ & 6.9 & DFA/culture & - & [41] \\
\hline 9 & Riyadh (2007-08) & 200 & $70(35)$ & $\begin{array}{l}\text { RSV-A: } 40(57) \\
\text { RSV-B: } 30(43)\end{array}$ & 35 & $\begin{array}{c}\text { RT-PCR } \\
\text { (N gene and F gene) }\end{array}$ & - & [48] \\
\hline 10 & Riyadh (2007-08) & 489 & $144(29)$ & RSV-1 (3) & 0.2 & PCR & - & [42] \\
\hline 11 & Riyadh (2008-09) & 175 & $39(22.4)$ & RSVA-23 (59) & 13.1 & Sequencing (G gene) & GA2 (NA1) & [46] \\
\hline 12 & Riyadh (2008-090 & 175 & $39(22.4)$ & RSVB-16 (41) & 9.1 & Sequencing (G gene) & BA & [56] \\
\hline 13 & Najran (2012-13) & 135 & $33(24)$ & $\begin{array}{l}\text { RSVA-30 (91) } \\
\text { RSVB-3 (9) }\end{array}$ & 24.4 & RT-PCR & - & [34] \\
\hline 14 & Riyadh (2008-09) & 174 & $117(67)$ & RSV-39 (22.4) & 22.4 & RT-PCR & - & [45] \\
\hline 15 & Riyadh (2014) & 130 & $28(21.5)$ & $\begin{array}{l}\text { RSVA-23 (82) } \\
\text { RSVB-5 (18) }\end{array}$ & 21.5 & Sequencing (G gene) & $\begin{array}{l}\text { NA1, ON1, } \\
\text { BA (BA9) }\end{array}$ & [57] \\
\hline 16 & Jazan (2013-14) & 182 & $75(41.2)$ & $\begin{array}{l}\text { RSVA-3 (25) } \\
\text { RSVB-9 (75) }\end{array}$ & 6.5 & Microarray & - & [35] \\
\hline 17 & Riyadh (2013-14) & 4611 & $1115(24 \%)$ & RSV-1086 (97.4) & 23.5 & DFA & - & [7] \\
\hline 18 & Riyadh (2014-15) & 2266 & $1013(44.5 \%)$ & $\begin{array}{l}\text { RSVA- 124(12) } \\
\text { RSVB- 212(21) }\end{array}$ & 14.8 & Real Time PCR & - & {$[44]$} \\
\hline
\end{tabular}


and other viruses have been identified by classical methods of viral detection, i.e. immunofluorescence assay, cell culture or ELISA (Table 1).

\section{Prevalence of $R S V$}

Respiratory viruses were identified by immunofluorescence assay in $62 \%$ of the 127 children hospitalized with ALRI in Riyadh during 1991- 1992. Fifty four percent of the cases were positive for RSV [36]. Another study included ALRI patients less than 2 years of age and detected RSV in 70\% of the samples by DFA and culture [37]. RSV accounted for $79 \%$ of the ALRI cases (less than 5 years of age) in hospitalized children in another study from Riyadh during 1993-96 [38]. A total of 1429 clinical samples were screened for respiratory viruses by immunofluorescence assay/ or cell culture in this study. RSV (29\%) was the most common viral pathogen detected followed by PIV-3 (3\%), Influenza A (1.6\%) and Influenza B (1\%) and adenovirus (1\%) by immunofluorescence assay in children hospitalized with ARI in Riyadh during 1993 to 1996 [39]. Immunofluorescence assay and ELISA was used by another investigator to detect RSV in $40 \%$ of the 51 children admitted for ALRI from Abha during 1997-2001 [32]. Study conducted in Riyadh has shown $19 \%$ of RSV prevalence during 1999-2003 [40]. In a study from Al-Qassim, RSV was detected in $128(45 \%)$ of the 282 samples collected from children admitted to a hospital with ALRI by direct immunofluorescence assay during 2003-04 [33]. In another investigation from Riyadh, RSV was identified in $7 \%$ of the ARI cases by immunofluorescence assay [41]. A study conducted in Riyadh has shown RSV co-infection with hMPV in 29 viral infected samples [42]. RSV was detected in $95.5 \%$ of the ALRI cases in a recent study from Riyadh [43]. Al-Ayed and colleagues also conducted a study in Najran and found 33 RSV (24\%) in 135 ARTIs [34]. A study from Riyadh has shown high percentage of RSV (97.4\%) among the total 1115 ARTI viral infected samples [7]. Investigation at Jazan by Abdulhaq and colleagues [35] showed low percentage (13.6\%) of RSV prevalence in 75 positive viral infected samples (Figure 2). A recent study conducted in Riyadh analysed 2266 paediatric patient NPAs/swabs with real-time PCR. The maximum RSV cases $(29 \%)$ were reported in winter season of 2014-15 [44]. The prevalence of RSV ranged between $0.2 \%$ to $54 \%$ with an average of $22.8 \%$ (Figure 3 ).

\section{Age wise distribution of RSV}

Many investigations have reported the age distribution of children enrolled for the RSV surveys.
Figure 1. Map of Saudi Arabia showing the regions where RSV studies are conducted (red star) and not conducted (green star) followed by year of collection of the samples. The map was created and edited in Microsoft PowerPoint. Maps are obtained online (http://www.presentationmagazine.com/world-mapsvector-editable-507.htm). Insert-World map showing position of Saudi Arabia (green).

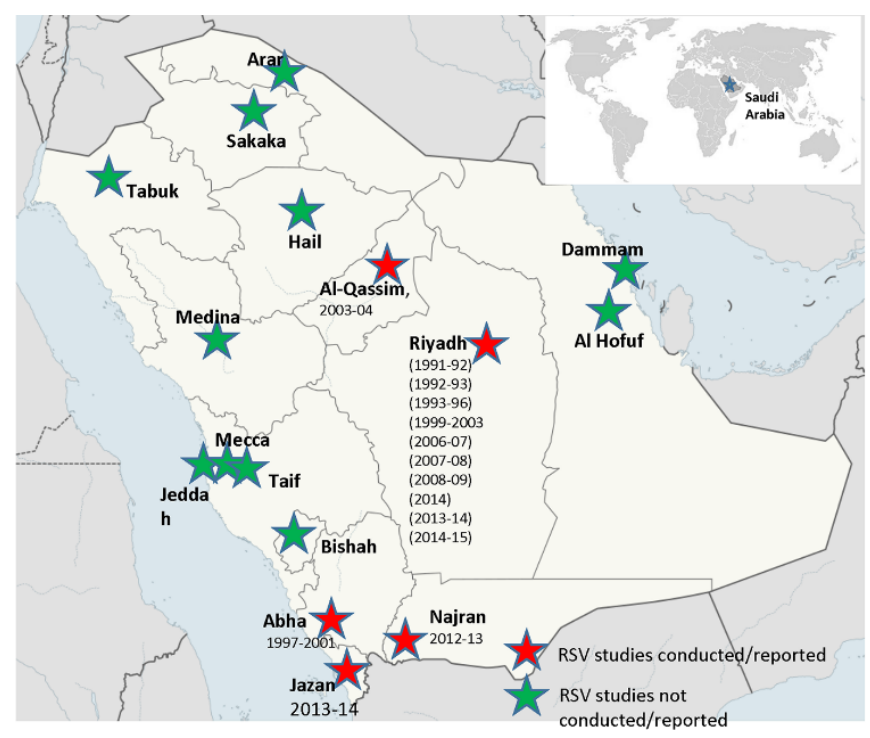

The maximum RSV infections were reported in patients less than 6 months of age (31-56\% of the positive cases) [32,45-47]. Other investigations have reported maximum RSV infection (54-70\%) in children less than 1 years of age $[7,33,34,48]$. These reports have concluded that most of the RSV infections in the pediatric age group occurred in less than one year age group. Such reports of higher prevalence of RSV in lower age group are also available from different

Figure 2. Number of total viral infections, total RSV infections and RSV-A and RSV-B infections reported in different studies from Saudi Arabia. Eighteen studies conducted correspond to the references in table 1 .

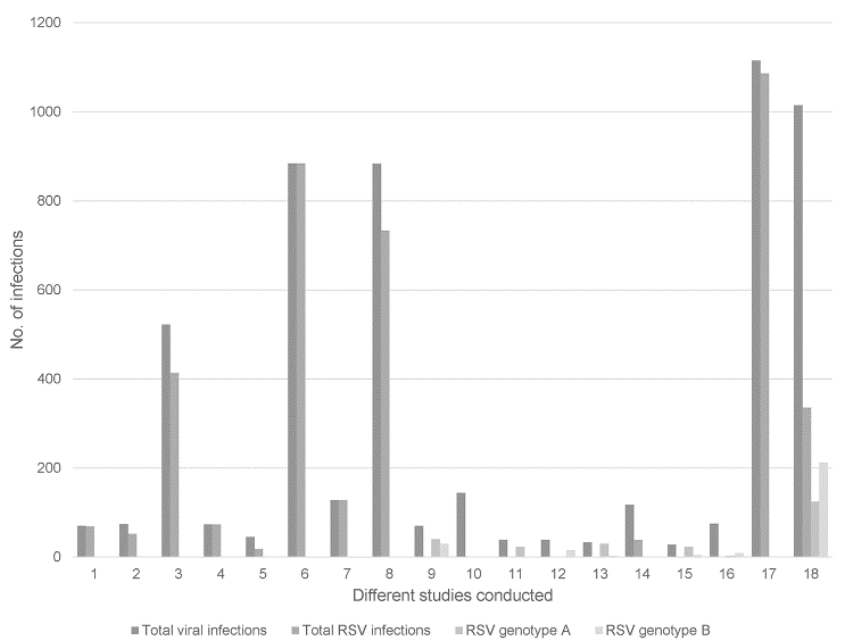


geographical regions [5,9]. However, the study conducted by Abdulhaq and colleagues include patients of all ages and they also found high prevalence of RSV in lower age group ( $<15$ years) [35].

\section{Gender distribution of RSV}

Many studies have reported the gender distribution of positive RSV cases. Most of the studies have reported that males (25-63\%) were more commonly affected by RSV as compared to females [34,35,44-48]. This probably is due to the fact that airways of male children are narrower than female counterparts leading to more frequent RSV infections [49-51]. Male predominance of RSV infections is also described from other countries [52-55]. However, Albogami and colleagues reported approximately equal distribution of RSV among male (30\%) and female (32\%) in Riyadh [7].

Thus, it is evident that most of the RSV studies were reported from the capital i.e Riyadh and one each from Abha, Qassim, Najran and Jazan (Table 1). Therefore, Additional data is needed from other regions of the country to determine the overall nationwide prevalence and true disease burden of RSV in Saudi Arabia.

\section{Seasonal distribution of $R S V$}

RSV causes seasonal infection as the outbreaks are reported during winter season in areas with temperate and Mediterranean climate and during rainy season in tropical/sub-tropical regions $[8,9,56]$. Different investigations from Saudi Arabia have suggested that most of the RSV infections are reported during winter months from this region $[7,8,39,44,45]$.

Figure 3. RSV prevalence in different studies from Saudi Arabia.

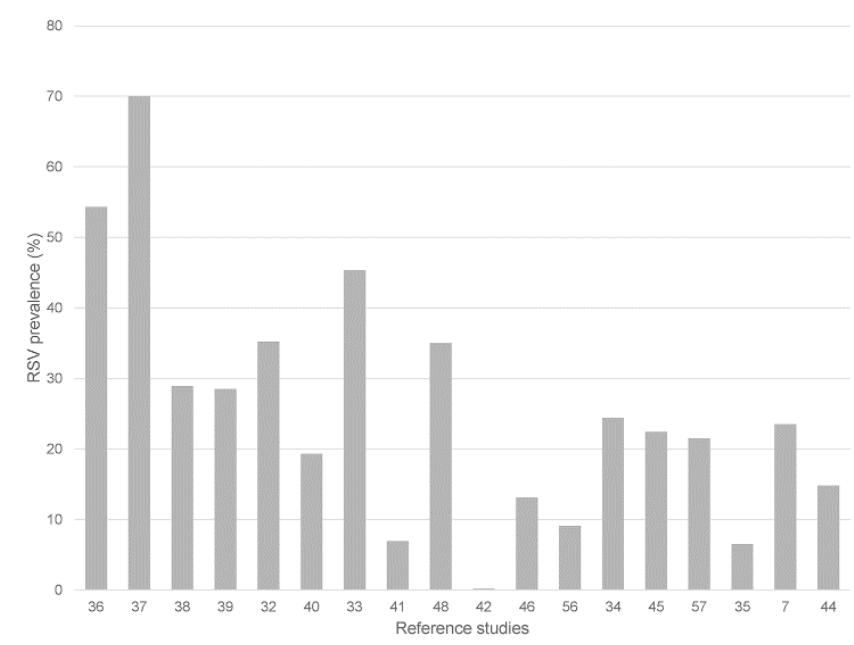

Clinical symptoms associated with RSV infection

RSV infections are presented with rhinorrhea, cough, sore throat and fever. In Saudi Arabia, RSV infections were most commonly associated with bronchopneumonia (57\%) or bronchiolitis (55\%) [33]. Other investigations reported $80-88 \%$ of bronchiolitis due to RSV in children less than 6 months of age $[32,38]$. Another study also confirmed that RSV was mostly associated with bronchiolitis in the pediatric patients from this region [37].

\section{Molecular epidemiology of RSV}

RSV has been demonstrated as important viral pathogen of ARI in Saudi Arabia but inadequate data is available on molecular epidemiology of RSV from the largest country in the Middle East. A few investigations have identified RSV in the clinical samples using rapid and more sensitive methods of detection such as PCR and real time PCR. An investigation from Riyadh identified RSV by RT-PCR for N and F gene [48]. Thirtyfive percent $(70 / 200)$ of the samples were positive for RSV by PCR, among which $57 \%$ were group A and 43\% were group B RSV. Almajhdi and colleagues have carried out molecular and phylogenetic analysis of RSV strains collected from pediatric patients ( 1 month to 3 years of age) with ARI symptoms from Riyadh during 2007/08 and 2008/09 in two different studies $[46,57]$. Twenty two percent of the samples (39) were positive for RSV of the 175 samples tested by RT-PCR in a study from Riyadh [46]. Group A RSV was detected in 59\% (23/39) and group B in $41 \%(16 / 39)$ of the positive samples. RSV was more prevalent in patients of less than 6 months of age with infection being more prominent in males than in females. An additional study from Najran identified RSV in 33 (24\%) of the 135 ARI patients of less than 5 years of age that were analyzed by RT-PCR during 2012- 2013 [34]. In a recent study from Riyadh RSV was reported in $39(22 \%)$ of the 174 samples collected from children less than 5 years of age during 2008-09 tested by real time PCR [45].

The comprehensive study of molecular characterization of group A and B Saudi strains of RSV was recently reported by our group from Riyadh [58]. We identified RSV by RT-PCR for the G protein gene in $27 \%(35 / 130)$ of the hospitalized children (less than five years of age) with ARI symptoms from Riyadh during 2014. This study further revealed that group A RSV was predominant $(27 / 35[77 \%])$ as compared to group B $(8 / 35[23 \%])$ in this region. Further, such elaborate studies on characterization of circulating 
strains from different regions are needed to define the disease burden due to RSV in Saudi Arabia.

Two more studies conducted from Riyadh, reported the prevalence of RSV in clinical samples. RSV was highly predominant $(97.4 \%)$ in 1115 viral positive samples in Riyadh [7]. Another study analyzed 2266 pediatric patient NPAs/swabs with real-time PCR in Riyadh and found $29 \%$ of RSV prevalence in winter season of 2014-15 [44]. From Jazan region, the RSV prevalence was $16 \%$ and group $\mathrm{B}$ RSV was predominant [35] (Table 1).

\section{Co-infection with other respiratory viruses}

Co-infection of RSV with other respiratory viruses like influenza, parainfluenza, adenovirus, hMPV and coronaviruses has been described in many investigations. Such mixed infections may increase the risk of severe disease as described previously $[59,60]$. In Riyadh, co-infection of RSV with influenza A was reported in $12(11.4 \%)$ of the samples [45]. Another study described co-infection with hMPV, rhinovirus and human coronavirus in $9(6.7 \%)$ of the patients [34]. Other investigations from regions of Saudi Arabia reported detection of various respiratory viruses like influenza $A$ and $B$, parainfluenza 1,2 and 3 enteroviruses and adenovirus along with RSV in the clinical samples [32,35,38,39,45]. A recent study reported the multiple viral infection with the RSVA (6.7\%) and RSVB (7.8\%) [44].

\section{Phylogenetic analysis of group A and group B RSV}

Very few studies have been carried out on characterization of circulating strains of RSV in Saudi Arabia. Characterization of RSV strains in these studies have been done by phylogenetic analysis using the study strains and GenBank sequences from different geographical regions. Almajhdi and colleagues have carried out phylogenetic analysis of group A and group B RSV strains from Riyadh in two different studies $[46,57]$. In the first study, the investigators analyzed circulating group A RSV strains [46]. The phylogenetic analysis of complete $\mathrm{G}$ gene sequences of the 10 group A RSV strains clustered within GA2 genotype. The majority of the study strains belong to the NA-1 subtype of the GA2 genotype. In another investigation, the same group worked on characterization of group B RSV strains from Saudi Arabia [57]. All the six group B strains clustered with the rapidly expanding BA genotype.

A comprehensive phylogenetic and molecular analysis of RSV strains was carried out by our group in a recent study from Riyadh [58]. Phylogenetic analysis clustered group A strains in the two genotypes i.e ON1 and NA1. All the group B study strains clustered in the BA genotype [58]. Interestingly, $26 \%$ of the positive samples clustered in the RSV genotypes with duplication in $\mathrm{G}$ protein gene i.e. ON1 and BA. Four and five strains were reported for the ON1 and BA genotypes respectively. This is the first study that described co-circulation of $72 \mathrm{bp}$ duplication group A (ON1) and 60bp duplication group B (BA) genotype from the largest country in the Middle East.

\section{Molecular analysis of RSV strains}

The molecular characterization of the Saudi strains was done by analysis of mutations, selection pressure, entropy and N-/O-linked glycosylation sites in a few investigations $[46,57,58]$.

\section{Mutation analysis}

The second hypervariable region of the G protein for both the groups of RSV of Saudi strains were used for the mutational analysis. Many amino acid mutations have been identified in both the groups of Saudi RSV strains as compared to the prototype strains $[21,25]$. All the NA1 and ON1 Saudi strains were predicted to encode for 297 and 321 amino acids respectively that are similar to the respective prototype strains. One common mutation at a position of 260 amino acid (N260S) was identified in the NA1 genotype that has been reported in two different publications [46,58]. Furthermore, all the BA Saudi strains had predicted length of 312 amino acids with three common mutations at K218T, L223P and S247P as compared to the prototype strain [25].

\section{Selection pressure}

The analysis of selection pressure of the group A and group B Saudi strains revealed low ratio of $\mathrm{dN} / \mathrm{dS}$ (non-synonymous to synonymous mutations) [58], suggesting that codons in this region of $\mathrm{G}$ gene are relatively conserved as described earlier [61]. Additionally, a few positively selected sites have been reported that indicate towards stochastic process of evolution of this region [18]. One particular positively selected amino acid at a 274 position in the ON1 genotype has been linked to the antibody escape mutants of RSV [18,62].

\section{Entropy analysis}

Shannon entropy analysis of the group A and group B Saudi strains revealed many variable sites suggesting amino acid variation at these amino acid positions. Two different amino acids at 274 and 219 positions in ON1 
and BA genotypes respectively, were identified to be positively selected as well as had high entropy values suggests variations at these positions [58]. The amino acid at 274 position was also reported to be positively selected in RSV strains from Philippines [17]. Further detailed site directed mutagenesis analysis on these two amino acids would determine their role in viral life cycle and pathogenesis.

\section{Glycosylation site analysis}

It has been postulated that $\mathrm{N}$ - and O-linked glycosylation of the $G$ protein contribute to the antigenic variation in RSV thus assisting the virus in host immune evasion [63]. At least two N-linked glycosylation sites have been predicted for all the Saudi RSV strains belonging to each of the three genotypes that are reported from this region i.e. NA1, ON1 and BA. Further, serine and threonine residues are the potential O-linked sugar acceptors. Many such serine and threonine residues (3-37) were reported in the second hypervariable region of $\mathrm{G}$ protein from Saudi strains $[46,57,58]$. Some Saudi strains showed additional glycosylation sites which may further contribute to antigenic variation in RSV $[46,57,58]$.

\section{Conclusions}

In conclusion, RSV is an important causative agent of ARI in Saudi Arabia. This is the first and comprehensive review of RSV infections from Saudi Arabia during last 25 years from 1993 to 2018. RSV investigations were mostly carried out in Riyadh, but epidemiological investigations should also be initiated at other geographical regions of the country. The survellence will provide valuable information of RSV prevalence in different climates and ethnic populations. Identification of the appropriate risk factors for the infection especially in the infants will enrich our understanding on the menace on this viral infection. Molecular characterizations of Saudi strains in some recent investigations have revealed the identification of NA1, ON1 and BA as the circulating genotypes in this region. Correlation of the disease severity with infecting viral genotype as well as the numerous climatic and genetic factors are other aspects that can be perused in the future studies. Therefore, additional elaborate clinical, virological and molecular surveillances in both hospital and community settings are needed to define the true disease burden and evolutionary dynamics of RSV from the largest country in the Middle East.

\section{Acknowledgements}

The study is a part of a project funded by the National Plan for Science, Technology and Innovation (MAARIFA), King Abdulaziz City for Science and Technology, Kingdom of Saudi Arabia with award number 12-MED2886-02.

\section{References}

1. Viegas M, Barrero PR, Maffey AF, Mistchenko AS (2004) Respiratory viruses seasonality in children under five years of age in Buenos Aires, Argentina: a five-year analysis. J Infect 49: 222-228.

2. Whimbey E, Champlin RE, Couch RB, Englund JA, Goodrich JM, Raad I, Przepiorka D, Lewis VA, Mirza N, Yousuf H, Tarrand JJ, Bodey GP (1996) Community respiratory virus infections among hospitalized adult bone marrow transplant recipients. Clin Infect Dis 22: 778-782.

3. Graham BS (2011) Biological challenges and technological opportunities for respiratory syncytial virus vaccine development. Immunol Rev 239: 149-166.

4. Bloemers BL, van Furth AM, Weijerman ME, Gemke RJ, Broers CJ, van den Ende K, Kimpen JL, Strengers JL, Bont LJ (2007) Down syndrome: a novel risk factor for respiratory syncytial virus bronchiolitis: a prospective birth-cohort study. Pediatrics 120: e1076-1081.

5. Nair H, Nokes DJ, Gessner BD, Dherani M, Madhi SA, Singleton RJ, O'Brien KL, Roca A, Wright PF, Bruce N, Chandran A, Theodoratou E, Sutanto A, Sedyaningsih ER, Ngama M, Munywoki PK, Kartasasmita C, Simões EA, Rudan I, Weber MW, Campbell H (2010) Global burden of acute lower respiratory infections due to respiratory syncytial virus in young children: a systematic review and meta-analysis. Lancet 375: 1545-1555.

6. Shi T, McAllister DA, O'Brien KL, Simoes EAF, Madhi SA, Gessner BD, Polack FP, Balsells E, Acacio S, Aguayo C, Alassani I, Ali A, Antonio M, Awasthi S, Awori JO, AzzizBaumgartner E, Baggett HC, Baillie VL, Balmaseda A, Barahona A, Basnet S, Bassat Q, Basualdo W, Bigogo G, Bont L, Breiman RF, Brooks WA, Broor S, Bruce N, Bruden D, Buchy P, Campbell S, Carosone-Link P, Chadha M, Chipeta J, Chou M, Clara W, Cohen C, de Cuellar E, Dang DA, DashYandag B, Deloria-Knoll M, Dherani M, Eap T, Ebruke BE, Echavarria M, de Freitas Lázaro Emediato CC, Fasce RA, Feikin DR, Feng L, Gentile A, Gordon A, Goswami D, Goyet S, Groome M, Halasa N, Hirve S, Homaira N, Howie SRC, Jara J, Jroundi I, Kartasasmita CB, Khuri-Bulos N, Kotloff KL, Krishnan A, Libster R, Lopez O, Lucero MG, Lucion F, Lupisan SP, Marcone DN, McCracken JP, Mejia M, Moisi JC, Montgomery JM, Moore DP, Moraleda C, Moyes J, Munywoki P, Mutyara K, Nicol MP, Nokes DJ, Nymadawa P, da Costa Oliveira MT, Oshitani H, Pandey N, Paranhos-Baccalà G, Phillips LN, Picot VS, Rahman M, Rakoto-Andrianarivelo M, Rasmussen ZA, Rath BA, Robinson A, Romero C, Russomando G, Salimi V, Sawatwong P, Scheltema N, Schweiger B, Scott JAG, Seidenberg P, Shen K, Singleton R, Sotomayor V, Strand TA, Sutanto A, Sylla M, Tapia MD, Thamthitiwat S, Thomas ED, Tokarz R, Turner C, Venter M, Waicharoen S, Wang J, Watthanaworawit W, Yoshida LM, Yu H, Zar HJ, Campbell H, Nair H (2017) Global, regional, and national disease burden estimates of acute lower respiratory infections due to respiratory syncytial virus in young children in 2015: a systematic review and modelling study. Lancet 390: 946-958. 
7. Albogami SS, Alotaibi MR, Alsahli SA, Masuadi E, Alshaalan M (2018) Seasonal variations of respiratory viruses detected from children with respiratory tract infections in Riyadh, Saudi Arabia. J Infect Public Health 11: 183-186.

8. AlMuhsen SZ (2010) Clinical profile of respiratory syncytial virus (RSV) bronchiolitis in the intensive care unit at a tertiary care hospital. Curr Pediatr Res 14: 75-80.

9. Cane PA (2001) Molecular epidemiology of respiratory syncytial virus. Rev Med Virol 11: 103-116.

10. Glezen WP, Paredes A, Allison JE, Taber LH, Frank AL (1981) Risk of respiratory syncytial virus infection for infants from low-income families in relationship to age, sex, ethnic group, and maternal antibody level. J Pediatr 98: 708-715.

11. Henderson FW, Collier AM, Clyde WA, Jr., Denny FW (1979) Respiratory-syncytial-virus infections, reinfections and immunity. A prospective, longitudinal study in young children. N Engl J Med 300: 530-534.

12. Hacking D, Hull J (2002) Respiratory syncytial virus-viral biology and the host response. J Infect 45: 18-24.

13. Anderson LJ, Hierholzer JC, Tsou C, Hendry RM, Fernie BF, Stone Y, McIntosh K (1985) Antigenic characterization of respiratory syncytial virus strains with monoclonal antibodies. J Infect Dis 151: 626-633.

14. Mufson MA, Orvell C, Rafnar B, Norrby E (1985) Two distinct subtypes of human respiratory syncytial virus. J Gen Virol 66: 2111-2124.

15. Johnson PR, Spriggs MK, Olmsted RA, Collins PL (1987) The $\mathrm{G}$ glycoprotein of human respiratory syncytial viruses of subgroups A and B: extensive sequence divergence between antigenically related proteins. Proc Natl Acad Sci USA 84: 5625-5629.

16. Sullender WM (2000) Respiratory syncytial virus genetic and antigenic diversity. Clin Microbiol Rev 13: 1-15.

17. Malasao R, Okamoto $\mathrm{M}$, Chaimongkol N, Imamura $\mathrm{T}$, Tohma K, Dapat I, Dapat C, Suzuki A, Saito M, Saito M, Tamaki R, Pedrera-Rico GA, Aniceto R, Quicho RF, Segubre-Mercado E, Lupisan S, Oshitani H (2015) Molecular characterization of human respiratory syncytial virus in the Philippines, 20122013. PLoS One 10: e0142192.

18. Esposito S, Piralla A, Zampiero A, Bianchini S, Di Pietro G, Scala A, Pinzani R, Fossali E, Baldanti F, Principi N (2015) Characteristics and their clinical relevance of respiratory syncytial virus types and genotypes circulating in Northern Italy in five consecutive winter seasons. PLoS One 10: e0129369.

19. Gimferrer L, Campins M, Codina MG, Martin Mdel C, Fuentes F, Esperalba J, Bruguera A, Vilca LM, Armadans L, Pumarola T, Antón A (2015) Molecular epidemiology and molecular characterization of respiratory syncytial viruses at a tertiary care university hospital in Catalonia (Spain) during the 20132014 season. J Clin Virol 66: 27-32.

20. Cui G, Zhu R, Qian Y, Deng J, Zhao L, Sun Y, Wang F (2013) Genetic variation in attachment glycoprotein genes of human respiratory syncytial virus subgroups a and $\mathrm{B}$ in children in recent five consecutive years. PLoS One 8: e75020.

21. Eshaghi A, Duvvuri VR, Lai R, Nadarajah JT, Li A, Patel SN, Low DE, Gubbay JB (2012) Genetic variability of human respiratory syncytial virus A strains circulating in Ontario: a novel genotype with a 72 nucleotide $G$ gene duplication. PLoS One 7: e32807.

22. Pretorius MA, van Niekerk S, Tempia S, Moyes J, Cohen C, Madhi SA, Venter M; SARI Surveillance Group (2013) Replacement and positive evolution of subtype A and B respiratory syncytial virus G-protein genotypes from 19972012 in South Africa. J Infect Dis 208 Suppl 3: 227-237.

23. Venter M, Madhi SA, Tiemessen CT, Schoub BD (2001) Genetic diversity and molecular epidemiology of respiratory syncytial virus over four consecutive seasons in South Africa: identification of new subgroup A and B genotypes. J Gen Virol 82: 2117-2124.

24. Arnott A, Vong S, Mardy S, Chu S, Naughtin M, Sovann L, Buecher C, Beauté J, Rith S, Borand L, Asgari N, Frutos R, Guillard B, Touch S, Deubel V, Buchy P (2011) A study of the genetic variability of human respiratory syncytial virus (HRSV) in Cambodia reveals the existence of a new HRSV group B genotype. J Clin Microbiol 49: 3504-3513.

25. Trento A, Galiano M, Videla C, Carballal G, Garcia-Barreno B, Melero JA, Palomo C (2003) Major changes in the $G$ protein of human respiratory syncytial virus isolates introduced by a duplication of 60 nucleotides. J Gen Virol 84: 3115-3120.

26. Dapat IC, Shobugawa Y, Sano Y, Saito R, Sasaki A, Suzuki Y, Kumaki A, Zaraket H, Dapat C, Oguma T, Yamaguchi M, Suzuki H (2010) New genotypes within respiratory syncytial virus group B genotype BA in Niigata, Japan. J Clin Microbiol 48: 3423-3427.

27. Baek YH, Choi EH, Song MS, Pascua PN, Kwon HI, Park SJ, Lee JH, Woo SI, Ahn BH, Han HS, Hahn YS, Shin KS, Jang HL, Kim SY, Choi YK (2012) Prevalence and genetic characterization of respiratory syncytial virus (RSV) in hospitalized children in Korea. Arch Virol 157: 1039-1050.

28. Blanc A, Delfraro A, Frabasile S, Arbiza J (2005) Genotypes of respiratory syncytial virus group B identified in Uruguay. Arch Virol 150: 603-609.

29. Etemadi MR, Othman N, Savolainen-Kopra C, Sekawi Z, Wahab N, Sann LM (2013) Biodiversity and clinicodemographic characteristics of human rhinoviruses from hospitalized children with acute lower respiratory tract infections in Malaysia. J Clin Virol 58: 671-677.

30. Etemadi MR, Sekawi Z, Othman N, Lye MS, Moghaddam FY (2013) Circulation of human respiratory syncytial virus strains among hospitalized children with acute lower respiratory infection in malaysia. Evol Bioinform Online 9: 151-161.

31. Trento A, Casas I, Calderon A, Garcia-Garcia ML, Calvo C, Perez-Breña P, Melero JA (2010) Ten years of global evolution of the human respiratory syncytial virus BA genotype with a 60-nucleotide duplication in the G protein gene. J Virol 84: 7500-7512.

32. Al-Shehri MA, Sadeq A, Quli K (2005) Bronchiolitis in Abha, Southwest Saudi Arabia: viral etiology and predictors for hospital admission. West Afr J Med 24: 299-304.

33. Meqdam MM, Subaih SH (2006) Rapid detection and clinical features of infants and young children with acute lower respiratory tract infection due to respiratory syncytial virus. FEMS Immunol Med Microbiol 47: 129-133.

34. Al-Ayed MS, Asaad AM, Qureshi MA, Ameen MS (2014) Viral etiology of respiratory infections in children in southwestern Saudi Arabia using multiplex reversetranscriptase polymerase chain reaction. Saudi Med J 35: 13481353.

35. Abdulhaq AA, Basode VK, Hashem AM, Alshrari AS, Badroon NA, Hassan AM, Alsubhi TL, Solan Y, Ejeeli S, Azhar EI (2017) Patterns of Human Respiratory Viruses and Lack of MERS-Coronavirus in Patients with Acute Upper Respiratory Tract Infections in Southwestern Province of Saudi Arabia. Adv Virol 2017: 4247853. 
36. Jamjoom GA, al-Semrani AM, Board A, al-Frayh AR, Artz F, al-Mobaireek KF (1993) Respiratory syncytial virus infection in young children hospitalized with respiratory illness in Riyadh. J Trop Pediatr 39: 346-349.

37. Chowdhury D, Al-Howasi M, Ramia S, Al-Frayh AR, Khalil M, Chowdhury S (1996) Respiratory syncytial virus in Saudi patients admitted to hospital with bronchiolitis: Use of direct fluorescent antibody tests as a rapid diagnostic tool. Ann Saudi Med 16: 90-92.

38. Bakir TM, Halawani M, Ramia S (1998) Viral aetiology and epidemiology of acute respiratory infections in hospitalized Saudi children. J Trop Pediatr 44: 100-103.

39. Al-Hajjar S, Akhter J, al Jumaah S, Hussain Qadri SM (1998) Respiratory viruses in children attending a major referral centre in Saudi Arabia. Ann Trop Paediatr 18: 87-92.

40. Shier MK, Badr MA (2005) Respiratory syncytial virus infection in patients visiting King Khalid University Hospital. Minoufiya Medical Journal 18: 11-18.

41. Akhter J, AlJohni SD, F., AlHefdi R, AlHassan I (2009) Etiology of respiratory viral infections using rapid virus isolation methods at a tertiary care centre in Riyadh, Saudi Arabia. Saudi Pharm J 17: 177-181.

42. Al-Hajjar S, Al Thawadi S, Al Seraihi A, Al Muhsen S, Imambaccus H (2011) Human metapneumovirus and human coronavirus infection and pathogenicity in Saudi children hospitalized with acute respiratory illness. Ann Saudi Med 31: 523-527.

43. Bukhari EE, Elhazmi MM (2013) Viral agents causing acute lower respiratory tract infections in hospitalized children at a tertiary care center in Saudi Arabia. Saudi Med J 34: 11511155.

44. Eifan SA, Hanif A, AlJohani SM, Atif M (2017) Respiratory tract viral infections and coinfections identified by Anyplex II RV16 detection kit in pediatric patients at a Riyadh tertiary care hospital. Biomed Res Int 2017: 1928795.

45. Amer HM, Alshaman MS, Farrag MA, Hamad ME, Alsaadi MM, Almajhdi FN (2016) Epidemiology of 11 respiratory RNA viruses in a cohort of hospitalized children in Riyadh, Saudi Arabia. J Med Virol 88: 1086-1091

46. Almajhdi FN, Farrag MA, Amer HM (2014) Genetic diversity in the $\mathrm{G}$ protein gene of group A human respiratory syncytial viruses circulating in Riyadh, Saudi Arabia. Arch Virol 159: 73-81.

47. Hirsch HH, Martino R, Ward KN, Boeckh M, Einsele H, Ljungman P (2013) Fourth European Conference on Infections in Leukaemia (ECIL-4): guidelines for diagnosis and treatment of human respiratory syncytial virus, parainfluenza virus, metapneumovirus, rhinovirus, and coronavirus. Clin Infect Dis 56: 258-266.

48. AlMajhdi FN, Al-Jarallah A, Elaeed M, Latif A, Gissmann L, Haitham MA (2009) Prevalence of respiratory syncytial virus infection in Riyadh during the winter season 2007-2008 and direct risk factors impact. Int J Virol 5: 154-163.

49. Meissner HC (2003) Selected populations at increased risk from respiratory syncytial virus infection. Pediatr Infect Dis J 22 Suppl 2: 40-45.

50. Gupta R, Helms PJ, Jolliffe IT, Douglas AS (1996) Seasonal variation in sudden infant death syndrome and bronchiolitisa common mechanism. Am J Respir Crit Care Med 154: 431435.

51. Sommer C, Resch B, Simões EA (2011) Risk factors for severe respiratory syncytial virus lower respiratory tract infection. Open Microbiol J 5: 144-154.
52. Muenchhoff M, Goulder PJ (2014) Sex differences in pediatric infectious diseases. J Infect Dis 209 Suppl 3: 120-126.

53. Lamarao LM, Ramos FL, Mello WA, Santos MC, Barbagelata LS, Justino MC, da Silva AF, Quaresma AJ, da Silva VB, Burbano RR, Linhares AC (2012) Prevalence and clinical features of respiratory syncytial virus in children hospitalized for community-acquired pneumonia in northern Brazil. BMC Infect Dis 12: 119.

54. Chan PK, Sung RY, Fung KS, Hui M, Chik KW, AdeyemiDoro FA, Cheng AF (1999) Epidemiology of respiratory syncytial virus infection among paediatric patients in Hong Kong: seasonality and disease impact. Epidemiol Infect 123: 257-262.

55. Falagas ME, Mourtzoukou EG, Vardakas KZ (2007) Sex differences in the incidence and severity of respiratory tract infections. Respir Med 101: 1845-1863.

56. Wahab AA, Dawod ST, Raman HM (2001) Clinical characteristics of respiratory syncytial virus infection in hospitalized healthy infants and young children in Qatar. J Trop Pediatr 47: 363-366.

57. Almajhdi FN, Farrag MA, Amer HM (2014) Group B strains of human respiratory syncytial virus in Saudi Arabia: molecular and phylogenetic analysis. Virus Genes 48: 252-259.

58. Ahmed A, Haider SH, Parveen S, Arshad M, Alsenaidy HA, Baaboud AO, Mobaireek KF, AlSaadi MM, Alsenaidy AM, Sullender W (2016) Co-circulation of 72bp duplication group A and 60bp duplication group B respiratory syncytial virus (RSV) strains in Riyadh, Saudi Arabia during 2014. PLoS One 11: $\mathrm{e} 0166145$.

59. Goka E, Vallely P, Mutton K, Klapper P (2013) Influenza A viruses dual and multiple infections with other respiratory viruses and risk of hospitalisation and mortality. Influenza Other Respir Viruses 7: 1079-1087.

60. Goka EA, Vallely PJ, Mutton KJ, Klapper PE (2015) Single, dual and multiple respiratory virus infections and risk of hospitalization and mortality. Epidemiol Infect 143: 37-47.

61. Parveen S, Sullender WM, Fowler K, Lefkowitz EJ, Kapoor SK, Broor S (2006) Genetic variability in the G protein gene of group A and B respiratory syncytial viruses from India. J Clin Microbiol 44: 3055-3064.

62. Botosso VF, Zanotto PM, Ueda M, Arruda E, Gilio AE, Vieira SE, Stewien KE, Peret TC, Jamal LF, Pardini MI, Pinho JR, Massad E, Sant'anna OA, Holmes EC, Durigon EL (2009) Positive selection results in frequent reversible amino acid replacements in the $\mathrm{G}$ protein gene of human respiratory syncytial virus. PLoS Pathog 5: e1000254.

63. Raghuram SV, Khan WH, Deeba F, Sullender W, Broor S, Parveen S (2015) Retrospective phylogenetic analysis of circulating BA genotype of human respiratory syncytial virus with 60 bp duplication from New Delhi, India during 20072010. Virus Disease 26: 276-281.

\section{Corresponding author}

Anwar Ahmed

Protein Research Chair, Department of Biochemistry, College of Science, King Saud University, King Khalid Road, PO Box-2455, Riyadh-11451, Saudi Arabia

Phone: +966114675932

Fax: +966114675791

E-mail: anahmed@ksu.edu.sa

Conflict of interests: No conflict of interests is declared. 